\title{
BIOSPHERE RESERVES - SUGGESTED MODEL OF THE INSTITUTION OF COMMONS (Case study of the Šumava Biosphere Reserve)
}

\author{
JAN TĚŠITEL, DRAHOMÍRA KUŠOVÁ
}

University of South Bohemia in České Budějovice, Faculty of Agriculture, Department of Landscape Management. Studentská 13, 37005 České Budějovice. e-mail: jtesitel@zf.jcu.cz;dkusova@zf.jcu.cz.

Received: $4^{\text {th }}$ September 2010, Accepted: $2^{\text {nd }}$ March 2011

\begin{abstract}
An attempt to address the interdependence between human economies and natural ecosystems has been articulated in ecological economics, among others, in terms of ecosystem services. Introducing ecosystem services yields positive result in the sense that the theoretical concept of cultural landscape has been complemented by the more or less effective political scheme, suitable as a basis for practical decision making. Nevertheless, practical management of ecosystem services on landscape scale is a rather complex task. The concept of institution of commons could be suggested to be used when dealing with the problem of implementation of ecosystem services concept in practice. The overall aim of the contribution is to discuss whether or not, or to which extent, UNESCO Biosphere Reserve, the modern strategy in biodiversity conservation backed up by internationally agreed upon conventions, can be used as a model for institution of commons in landscapescale nature protection. The discussion is based on empirical evidence gained within a longterm research conducted in the Šumava Biosphere Reserve, Czech Republic.
\end{abstract}

Key words: Biosphere reserve, Institution of commons, Rural tourism, Šumava Mts.

\section{INTRODUCTION}

\section{Cultural landscape as a socio-ecological system}

Carl Troll (1939) is supposed to have coined the term of landscape ecology as scientific discipline. He considered landscape ecology a „perfect marriage between geography and biology". Since, this branch of science has developed profoundly, partly as a response to challenges evoked by changing face of landscape. According to Antrop (2007), in the densely populated Europe, the main concern is on cultural landscapes. For traditional landscapes the focus is on the loss of ecological and heritage values and on natural and cultural capital. Apart from analyzing the past, there is also a growing need to plan future landscapes in an increasingly urbanized society and polarized environment. All this happens in the perspective of sustainable development and participatory planning. Stepping on this ground, landscape ecology seems to partly overlap with theories of regional development (Blažek and Uhlír 2002). In this perspective, a landscape can be considered a scale of economic organisations and political interventions (Amin and Thrift 1994; Storper 
1997; Maskel and Malmberg 1999; MacLeod 2001) and the notion of network is introduced, built upon social relationships which provide security and trust (Lowe 1988). Consequently, behavior of particular stakeholders in terms of their mutual interactions becomes a focal point of the current research (Massey et al. 1994; Gunjan et al. 2007). Simultaneously, the stress is put on institutional structures (Ostrom 1990, 1999; Agrawal 2001), as „institutions make the game, so they represent existing distribution of power“ (Wood et al. 2000; Stoll-Kleeman et al. 2006). Summed up, once policies, social institutions and decision-making processes have been recognized crucial vehicles for landscape change, their nature as well as effects have become a subject of landscape ecological research, as an important parameter of behavior of landscape articulated in terms of social-ecological system (Holling 2001).

An attempt to address the interdependence between human economies and natural ecosystems has been articulated, among others, in terms of ecosystem services (e.g. Costanza et al. 1997; Brock and Xepapadeas 2003; Imhoff 2004; Millennium Ecosystem Assessment 2005; Faber 2008) - the conditions and processes by which natural ecosystems, and the species that make them up, sustain and fulfil human life Daily (1997). Introducing ecosystem services yields positive result in the sense that the theoretical concept of cultural landscape (Antrop 2001, 2007; Naveh 2001, 2007; Palang et al. 2005) has been complemented by the more or less effective political scheme, suitable as a basis for practical decision making. Nevertheless, practical management of ecosystem services on landscape scale is a rather complex task. Within the wide range of challenges, institutional arrangement which could moderate competition among particular services and interest groups, engaged with these services, could be considered as essential ones (Moldan and Hák 2010). Moreover, there is still a problem of scale, i.e. the institutional level at which crucial decisions on the management of concrete ecosystem are made - local or extra-local. This problem opens much broader discussion on the role of local communities in decision making process on future development of a region or a locality they live in (Těšitel et al. 2006) or in other words, question on who ultimately has the legitimacy to define or at least to negotiate identity of a particular locality (Bauman 1999).

\section{Institution of commons}

Landscapes, as a rule, can be defined as public territories (Andereck 1997) as they have two distinguishing characteristics of commons - nonexludability and subtractability/rivality - in addition to being indivisible and with ,fluid“ boundaries (Jafari 1982; Healy 1994; Briassoulis 2002). As such they are supposed to be subject of multiple uses by diverse groups, characterized by multiple, overlapping and potentially conflicting uses; volatility in uses and institutional arrangements; and variances between de jure an de facto property rights (Selsky and Memon 2000). As their particular components are supposed to be under diverse property regimes - state, private, communal or open access, different producers and management systems are involved with different concerns as regards their use and protection.

The general efficiency problem of any resource user is to reduce or eliminate externalities related to resource management. Since the mid of eighties, discussions over what kind of institutional arrangements account for sustainable landscape management have focused on locally situated small user groups and communities, addressing issues such as common property arrangements and common-pool resources (McCay and Acheson 1987; Berkes 1989; Ostrom 1990; Agrawal 2001a). The research on the commons has shown that resources users often create institutional arrangements and management regimes that help them allocate benefits equitably, over long time periods, and with only limited efficiency 
losses (McKean 1992; Ostrom 1992; Agrawal 1999). In light of this knowledge, central state interventions, markets or privatization of property rights over resources have become less likely proposed as a matter of course. Rather, conditions under which communal arrangements compare with private or state ownership have been analyzed, especially where criteria such as equity, justice and sustainability are concerned (Baland and Platteau 1999; Agrawal 2001).

The idea of empowerment of local institutions in management of local resources has been echoed as well in the Czech professional literature, in particular in the relation with the Program of countryside revitalization. According to Blažek in Cílek (2010), the renaissance of countryside should not be seen as a return to one specific date, but to the vital principle of the countryside's existence - permanent re-creation of itself. Revitalization of countryside, in this sense, is performed the better the less „experts“ on countryside revitalization are participating, as the process should essentially be guided by the local socio-ecological system itself, i.e. by nature in partnership with local people.

\section{Nature protection}

Management of large-scale protected areas can be used to document the problem of competition related to multiple use of a landscape. In Central Europe, where cultural landscape is subject of protection, management of protected areas may face the difficulty to reconcile the conflict between relative new, worldwide, conservation paradigm and historically formed local land-use practices. If not managed properly, the conflict leads to the situation when stereotype in thinking emerges, adopted by experts as well as general public presuming nature protection measures to be a-priori in contradiction with socioeconomic development. For nature conservationists, „marketing“ of protected areas is something ,dirty“, „commercial“, not ,suitable“ for the field of nature protection (Roth 2007). On the other side, nature protection have a poor image as it is mainly perceived as a burden for regional development by local and regional entrepreneurs as well as general public (e.g. van Kooten and Wang 1998; Paiders 2007).

There are historically two approaches as to protected areas management, principally differing in a way they consider local population, more specifically the degree to which local residents are expected to be involved in decision making processes and management responsibilities (Hayes 2006). Traditional conservation model prioritizes state-mandated designation of nature protection that prohibits human residents and strictly regulates consumptive and non-consumptive activities (Ghimire and Pimbert 1997). The other model is based on the presumption that successful conservation depends on greater community participation and control over protected areas creation and management decisions (Western and Wright 1994; McNeely 1995; Stevens 1997; Western 1997). Advocates of participatory conservation approaches insist that by denying local people access to protected areas and by excluding them from decision-making processes, conservationists create tensions between protected areas managers and local residents, increase monitoring costs, and fail to benefit from valuable local knowledge and resource management systems (Wells and Brandon 1992). Such an integrative approach emphasizes social and political implications of establishing of protected areas, supporting thus criteria such as equity and justice to be incorporated into environmental decision making (Been 1993; Bullard 1994; Bryant 1995; Imperial 1999).

Although the importance of local community engagement in protected areas management has been widely recognized and analyzed in the academic literature, there is limited evidence that community participation has become widespread practice or been effective in influencing the nature and scale of development (Goodal and Stabler 2000; Petrova et al. 
2009). It is partly due to a wide range of institutional and administrative challenges it faces, main problem being its low compatibility with the current institutional environment premised on centralized control over nature protection (e.g. Pimbert and Pretty 1995; Imperial 1999; Parto 2005; Stoll-Kleemann et al. 2006).

As in its entirety, community participation opens opportunity for incorporation of widely different levels and qualities of involvement on local level (Petty 1995), most of the existing models for local community participation in protected areas management have mainly been based on the experiences of relatively stable and developed democratic societies (Hall 2000). In Central and Eastern European countries however, there is currently no tradition enough with democratic multilevel decision making. The main problem could be described in terms of cognitive lock-in of state administration bodies in communication with nongovernmental sphere (Kluvánková-Oravská and Chobotová 2010). These actors, such as private firms and non-profit organizations, are still viewed in their traditional roles of opponents or advocates, rather than as partners (Imperial 1999). As a result top-down management models are still overwhelmingly utilized as a result of the chronic lack of research and policy awareness relating to the ecological, socio-political and economic factors that influence efficient local community participation in protected areas governance, biodiversity conservation, and rural development more generally (Welsh and McShane 2004).

\section{The concept of UNESCO biosphere reserve}

Very important in this context is the definition of nature protection as it was formulated by IUCN in its World Conservation Strategy. In fact it was anthropocentric as it considered nature protection to be a management of air, water, soil, mineral resources and living systems, including man, aimed at achieving sustainable quality of life (IUCN 1980). Later on, the strategic shift was reflected by the UNESCO concept of biosphere reserves as it was articulated in the Seville Strategy and reinforced in the Madrid Declaration. According to its guiding idea, biosphere reserve is to strengthen general awareness of mutual interrelations between humankind and biosphere by ensuring its four functions - enabling high-level biodiversity protection, supporting research and education, and promoting sustainable forms of socioeconomic development (UNESCO 1996, 2001, 2002, 2008). By promoting the idea that the management of each biosphere reserve should be essentially formulated as a ,pact' between the local community and the society as a whole, the concept invites all interested groups and sectors for participation in a partnership approach. Doing so it acknowledges the fact that the capacity (e.g. knowledge, power and resources) to solve complex problem related to the implementation of the biosphere reserve concept is often widely dispersed among a set of actors located on different scales (e.g. Imperial 1999). Such an approach seems to fully reflect the general tendency of the last decades embodied in the gradual shift from government towards governance, where responsibility for policymaking spans public and private sectors, promoting thus increased interest in networks as an organizational concept when conducting joint action (Murdoch 2000; Hajer 2003a; Gunjan 2005; Parto 2005; Dredge 2006). Policy making under the new conditions has become a matter of defining an agreed upon package of actions to be taken by variety of stakeholders, often supported by „soft law“ such as conventions or agreements (Hajer 2003). In this perspective, network structures are built upon social interactions and relationships which provide security and trust (Lowe 1988; Tait and Lyall 2004). Biosphere reserves, fundamentally concerned with whole-of-landscape processes, across a variety of land tenures and uses can be thus seen institution appropriate for managing the social, 
cultural processes at the multiple scales (Amin and Thrift 1994; Storper 1997; Maskel and Malmberg 1999; MacLeod 2001; Brunghorst 2001).

In this context, the overall aim of the contribution is to discuss whether or not, or to which extent, UNESCO Biosphere Reserve, the modern strategy in biodiversity conservation backed up by internationally agreed upon conventions, can be interpreted as a model for institution of commons in landscape-scale nature protection.

\section{Modul area}

Šumava Biosphere Reserve, Czech Republic was chosen as a model area for the analysis. The Šumava Mts. region is represented by a mountain range situated in the south west part of the Czech Republic. Thanks to its geographical position this area retained its natural character almost by the end of the first half of $20^{\text {th }}$ century (Fig. 1). Settlements and natural resources exploitation, however, were there for centuries - particularly glass making and wood processing industry - and was leading to a long tradition of harmony between man and nature. The post war period of development was characterised by ethnic shift in 1946 . Establishing of „iron curtain“ and military training areas in this territory were other specific phenomena the territory was famous of. Location on the border separating the East and West European political alliances, distance from political-economic and cultural centres and a predominantly rural landscape were the main factors maintaining the region economically marginal. On the other hand, natural beauties of the area sustained preserved. As a result, large-scale nature protected areas were proclaimed there - the Sumava Protected Landscape Area in 1963 and the Šumava National Park in 1991. Extending quality of nature was recognized as well internationally and since 1990 most of the mountain range has a statute of the UNESCO biosphere reserve. Political change that took place in Central and Eastern Europe in 1989 introduced quite new situation. By this process the Šmava Mts. region was plunged immediately into European context having thus a chance of ceasing to be marginal.

Fig. 1: Šumava Mts. - scenic view. Photo Michael Bartoš.

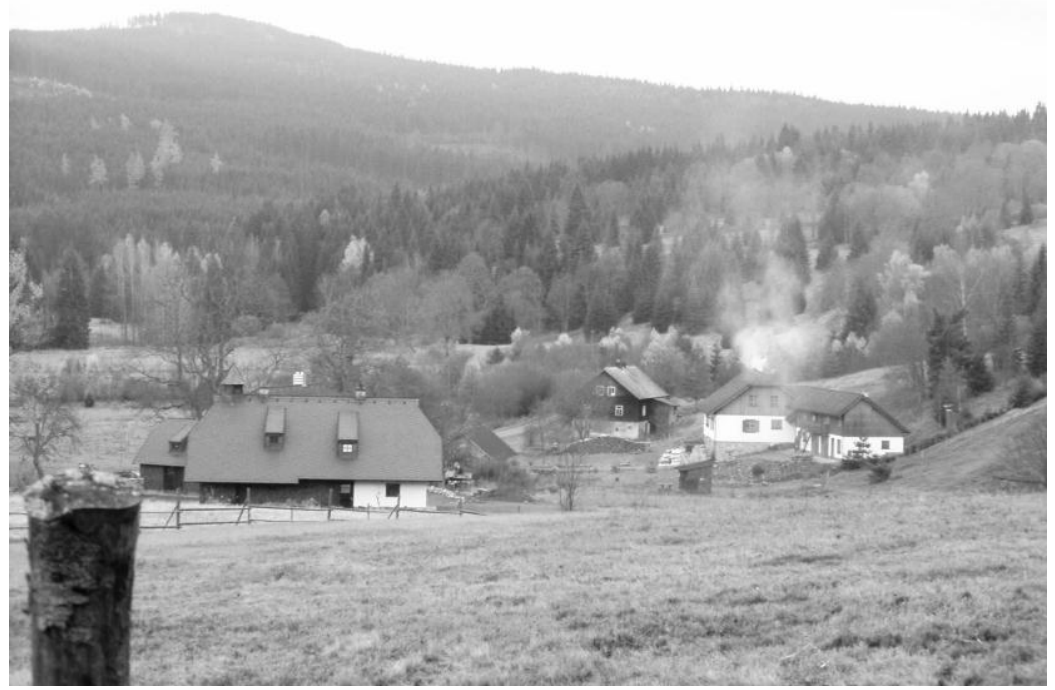




\section{METHODS USED}

Generally, the discussion is based on empirical evidence gained within a long-term research conducted in the Šumava Biosphere Reserve, Czech Republic ${ }^{1}$. More specifically it builds on case study analysis conducted recently. The project „Sound tourism - a chance for the Šumava Biosphere Reserve" became the subject of the analysis whose aim was to identify success and failure factors of its practical implementation. Institutional aspects of the implementation process were given special attention.

\section{RESULTS}

\section{Institutional status of biosphere reserve in the Czech Republic}

Biosphere reserve is not recognized as a legal category of protected areas by the Czech environmental legislation. The Act of Nature Conservation and Landscape Protection does not include biosphere reserve when defining six national protected area categories: national park, protected landscape area, national nature reserve, national nature monument, nature reserve and nature monument. Biosphere reserve is then perceived as an international label stuck on an area already protected according to the national environmental legislation that does not have any legal support (Urban 2006). Institutionally, the management of biosphere reserve is associated to the administration of protected landscape area, or national park. The space to manoeuvre when trying to implement the concept in practice is then a-priory undefined, depending thus on local initiatives. In other words, such a situation opens space for building local arrangements on how to practically deal with this concept. Identification of consensual economic activity, i.e. activity that „compatible“ with the nature conservation interests that, at the same time could guarantee acceptable socio-economic development of the territory, could be suggested as the possible way how to start the process of biosphere reserve concept implementation. Rural tourism has appeared to be the appropriate consensual activity in the case of the Šumava Biosphere Reserve.

\section{Šumava Mts. as a tourist destination}

Sumava Mts. has a reputation of traditional tourist destination dating back to the end of $18^{\text {th }}$ Century (Fig. 2). Numbers of tourists and particular forms of tourism had been changing over time, the motivation to visit the region however, sustained the same - search for beautiful nature, quiet, and physical exercise (Těšitel et al. 2003). Since the beginning of nineties, tourism has been expected to become the most important factor forming the future of the region (Fig. 3). Recognition of attractiveness of the territory for tourists as the most promising attribute of the region had the evidently the ground in a very good knowledge of local people not only as regards the natural beauties of the territory but also as regards the local socioeconomic situation of that times. The territory was historically equipped with recreational facilities of different kind, as it has been a target territory for

\footnotetext{
${ }^{1}$ Projects: - Sustainable development strategy for Šumava Biosphere reserve. GEF - Biodiversity protection in the Czech Republic, World Bank, 1995 - 1997

- Carrying capacity and revenue mechanisms for Šumava Biosphere reserve, GEF - Biodiversity protection in the Czech Republic, World Bank, 1995 - 1997

- Participative management of protected areas - key to minimize conflicts between conservation of biodiversity and socioeconomic development of local communities, VaV Ministry of the Environment of the Czech Republic, 2003 - 2005
} 
Czech as well as foreign tourists for a long time. There have been facilities as well as tradition which new development has been based on (Těšitel et al.1999).

Fig. 2: Touristic observation tower in Čerchov - historical postcard

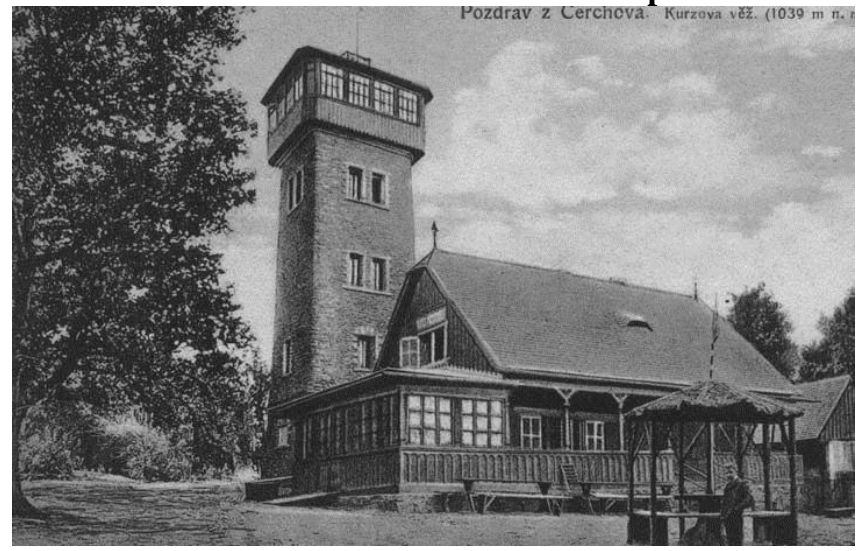

Fig. 3: Promising business branches in the Šumava Mts., as seen by local population in 1997. Source: own field survey conducted within the GEF project „Sustainable development strategy for the Šumava Biosphere reserve 1995-1997“, N= 500.

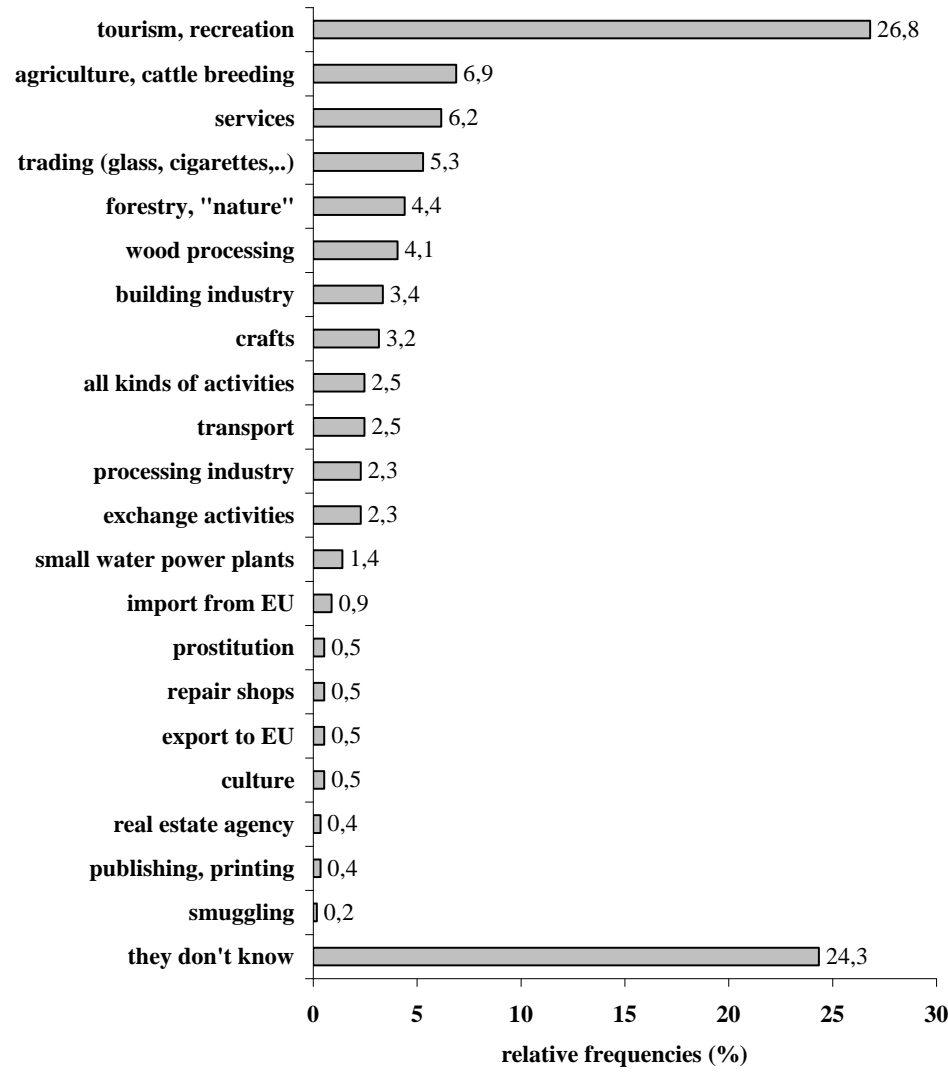




\section{Nature-tourism interdependency}

„Sound environment“" and „well-preserved nature“" are two principal attributes of the territory considered to represent comparative advantage for further socio-economic development. The fact that the Šumava Mts. was recognized as tourist destination means in fact setting of the region into the context of the nation-wide or even international market. By use of it the internal potential of the locality could be commodified. Once we agreed with locals and assume that rural tourism could be considered the base of the local economy in area where „certified nature“ is the prominent touristic attractor, the positive role of nature protection appears to be evident. As this type of tourism can be characterized, among others, as one that commodify local natural capital of certain quality (Kušová et al. 2002; Nolte 2005), we could formulate a theoretical statement, to some extent paradoxical, that it is the nature protection, as a guardian of certified nature, that can guarantee local economic development in long run as it keeps promoting comparative advantage of an area (e.g. Bartoš et al. 1998; Těšitel et al. 1999; Těšitel et al. 2003a). What is even more important is the fact that locals seem to acknowledge this aspect of nature protection as well, which has lead to some changes in their attitudes towards NP and PLA administration recently (Kušová et al. 2008, 2008a).

\section{Network of actors and network of projects}

The importance of sound tourism in biodiversity protection was recognized internationally, as can be documented by financial support of UNEP-GEF made to the project titled „Conservation and Sustainable Use of Biodiversity through Sound Tourism Development in Biosphere Reserves in Central and Eastern Europe“, rephrased in the region as „Sound Tourism - A Chance for the Šumava Biosphere Reserve“. It was initiated by the ŠNP administration and had actually a form of a gesture. The end-user of the project outputs, however, was defined as the entire territory of the Šumava Biosphere Reserve. The mission of the project was twofold - besides producing outputs of its particular activities, it was intended to be a tool facilitating communication between the protected area administration and other stakeholders involved in the project. That is how it was functioning since the very beginning. The project proposal was elaborated by a team consisting of the representatives of all local groups interested in relevant fields - nature conservation, local entrepreneurs, communities, representatives of regional governments and NGOs. Considering our point of view, it is important to mention the Local Steering Committee of the project, comprising those who were in charge of the project preparation. In the period of project implementation its members participated in the project management as well as in lobbying for widening the scope of the project activities, and for further fundraising.

The project could be considered a set of nine interlinked activities which span from those having very practical outputs to activities producing strategic planning materials. „Establishment of a System of Cross Border Tourist Trails“, „Training of Local Guides“ and „Identification of a Potential of the Šumava Biosphere Reserve for New Touristic Activities" can be seen as the most practical outputs of the project, having immediate impact on the territory. There were two activities within the project directly supporting sustainable forms of tourism - „System of Financial Incentives“, having a form of local grant scheme aimed primarily at improving small scale touristic infrastructure, and „System of Certification of Local Products and Services“. Among the strategic activities we can count participation of the project in preparation of the „Concept of Sustainable Tourism Development in the Šumava Region“, „Institutional Analysis of the Šumava Biosphere Reserve“ and designing of an electronic „Database on Cultural Heritage of the Sumava 
Biosphere Reserve". Designing of platform for information exchange among local mayors, representatives of nature protection authorities and other key stakeholders became an inseparable part of the project, manifested in the form of series of round tables and training courses (Fig. 4),

Fig. 4: Round table with mayors of the Šumava Biosphere reserve villages - Modrava, July 3, 2007. Photo Jan Těšitel.

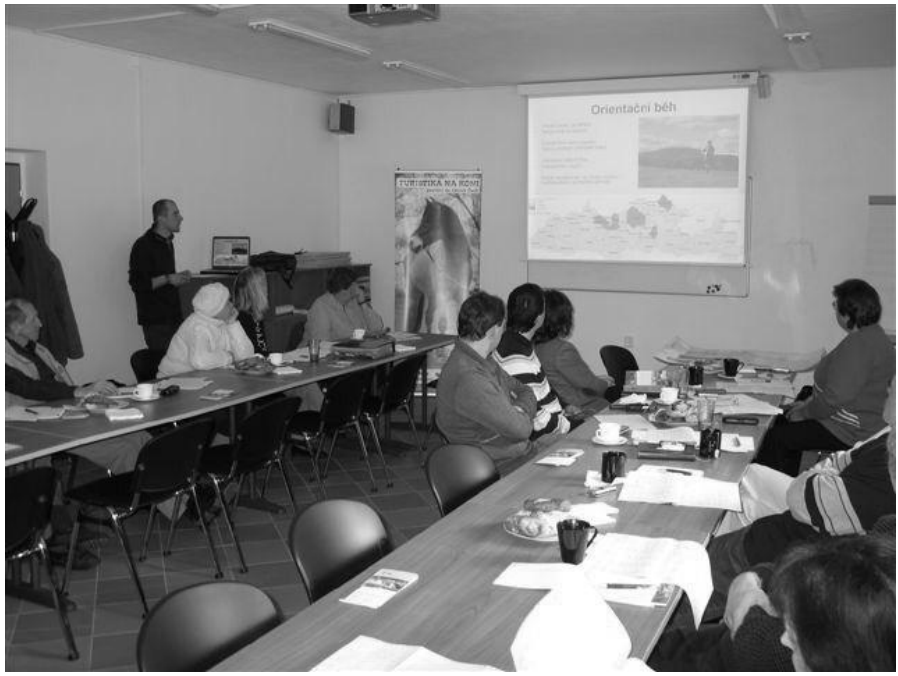

The scope of the project was too complex to be executed by one expert or institution. As a result, one of its main „social by-products“ was an establishment of several social networks, partly overlapping, by use of which particular project activities were realized. Šumava National Park and Protected Landscape Area Administration, Regional Development Agency Šumava, Regional Environmental Centre Czech Republic, as well as NEBE Agency formed a core of these networks, coordinated as a rule by the Institute of Systems Biology and Ecology AS CR. In parallel to forming social networks, network of projects emerged around individual activities. In this manner, the UNEP-GEF project was linked with two INTERREG-type projects - PANet (Protected Areas Networks Establishment and Management of Corridors, Networks and Cooperation) and Certification of Local Products in the Sumava Mts., pooling thus experts, know-how and financial resource with the aim to use them as much as effectively ${ }^{2}$ (Těšitel et al. 2007; Kušová et al. 2008a).

The complexity of the problems solved by the projects has resulted in time chaining. Viewed from this perspective, the projects network proved to be an efficient impetus to start solving the problems, delivering however, neither financial sources nor time enough to accomplish the task in its full extent. As the networks of interested partners has already been established, some projects activities are expected to continue in the future, supported

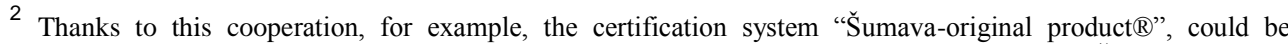
extended to include certification of services related to sound tourism as well. As a result, the Šumava Mts. has become region where the certification system has been developed best, compared to other regions within the Czech Republic 
however by another grants, both running and applied for. The projects network thus spans far beyond the „lifetime“ of particular projects, setting a base for a long term activities related to the concept of biosphere reserve. In particular, the system of local guides was adopted by the Šumava National Park Administration and included into its regular agenda (Fig. 5) ${ }^{3}$. Similarly, the project aimed at building the cultural heritage database was extended to include Bavarian side of the region and continues under the umbrella of the Czech-Bavarian cross-border cooperation scheme, having the name „Historical topography of the region Silva Gabreta-Egrensis“"(Fig. 6) ${ }^{4}$.

\section{Fig. 5: Leaflet promoting services delivered by local guides (2007)}

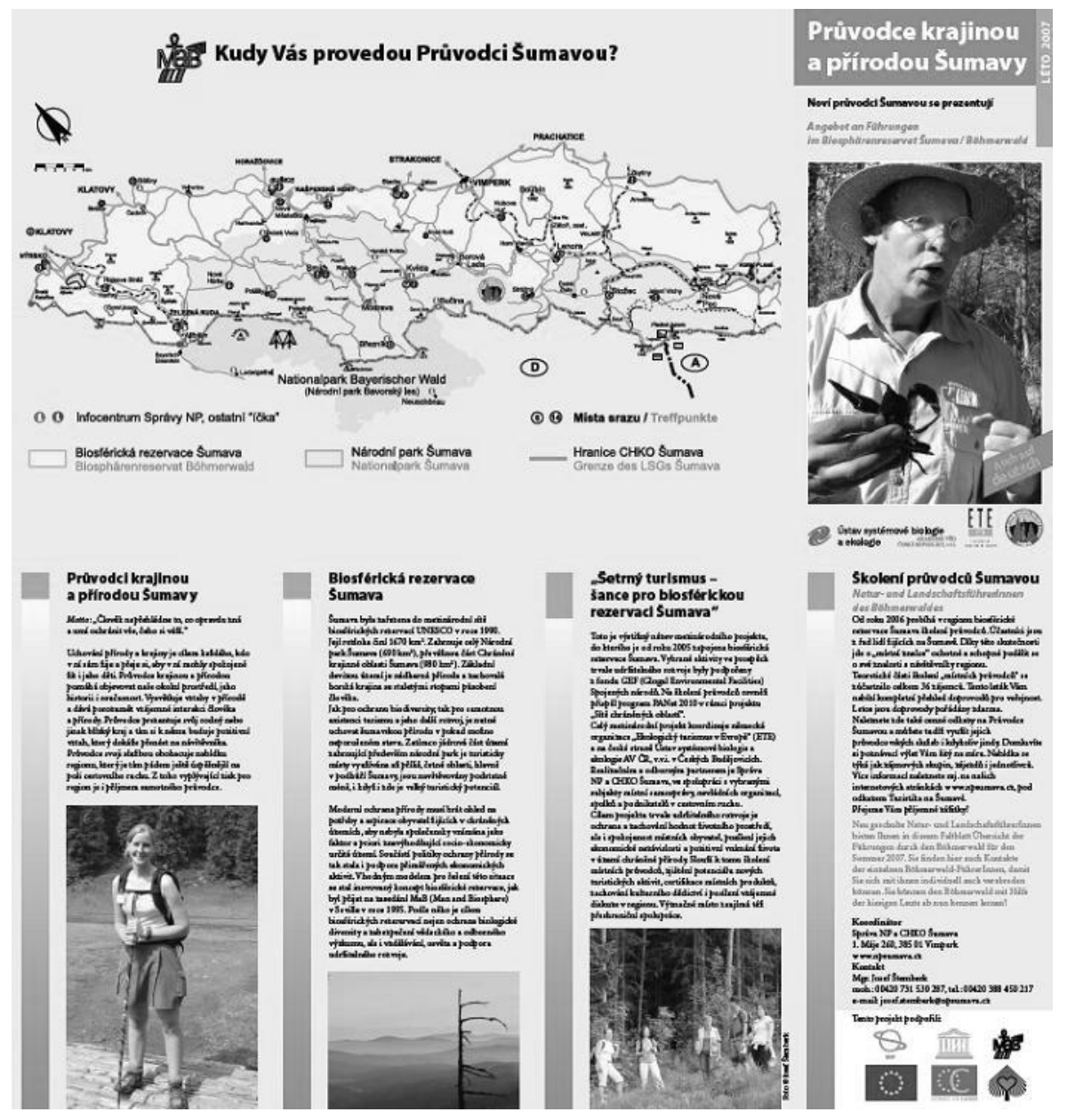

\footnotetext{
${ }^{3}$ http://www.npsumava.cz/1072/sekce/pruvodci-sumavou/

${ }^{4}$ http://www.regioskop.eu/index.html
} 
Fig. 6: Homepage of the project „Historical topography of the region Silva Gabreta-Egrensis“"

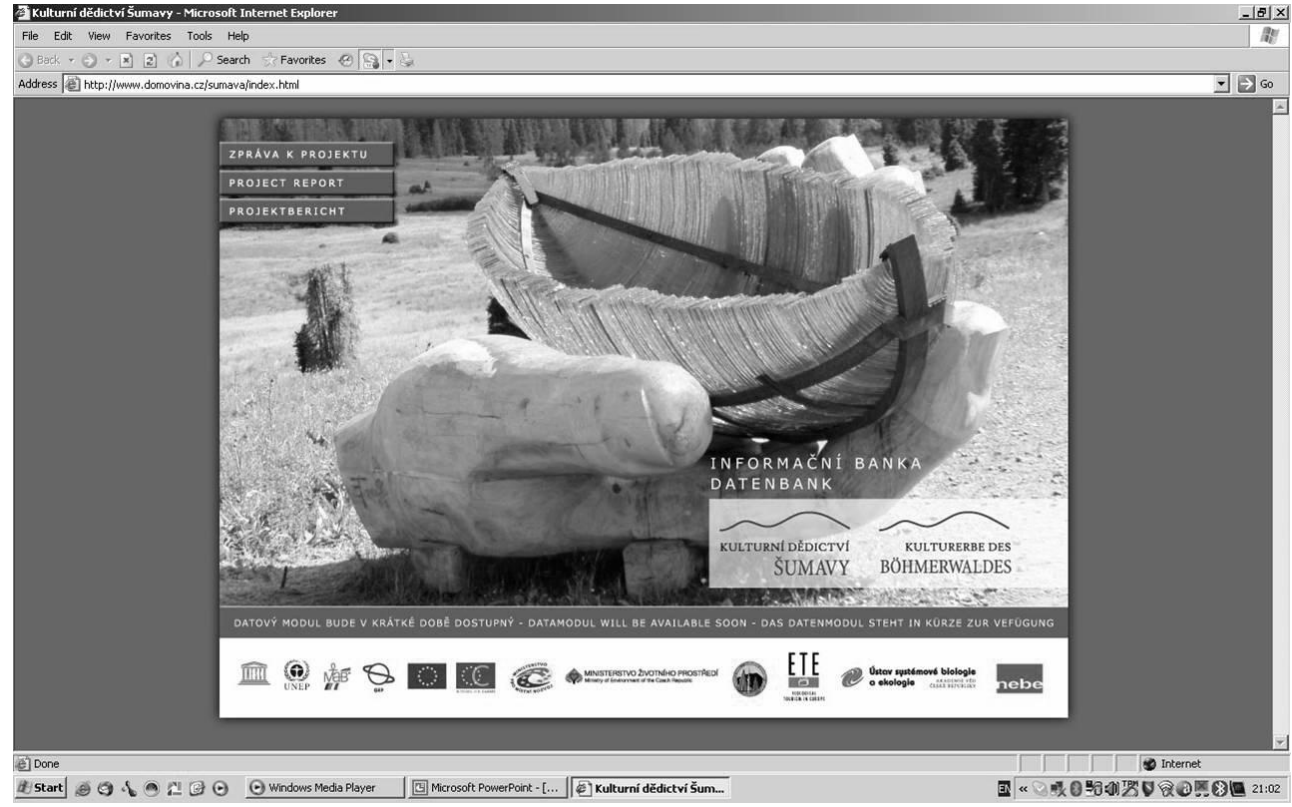

\section{DISCUSSION AND CONCLUSIONS}

The role of rural tourism as a potential mediator in the process of the biosphere reserve concept practical implementation has appeared to be closely tied up with its two implicit characteristics - fragility of rural tourism and its potential for networking. Firstly, its close association with the attributes of rurality means at the same time fragility of its development as rural tourism booms or goes down in dependence on quality of these attributes (Hillery et al. 2001; Těšitel et al. 2003a; Gunjan et al. 2007). Secondly, in community tourism analyses, the tourism system is frequently described as highly fragmented (Shaw and Williams 1994). This observation has led to assumption that no single organization or individual can exert direct control over the destination's development process (Jamal and Getz 1995), and individual actors often rely on coalitions with others. The role of collaboration in tourism has been explored at length (Bramwell and Lane 2000), reflecting an increasing recognition that partnerships are, or should be, an integral component of local tourism development (Long 1994). The need for cooperative approaches arises from a change in the competitive strategies that are influenced by the volatility and sensitivity of tourism industry (Gunjan 2005) that requires key actors to think about which of their resources and activities are most sensibly combined (Crompton 1990; Palmer 1998). As a result, networks emerge, forming institutional setting for information exchange and learning process among particular stakeholders.

In our case that network of projects fulfilled two types of expectations - it produced outputs good by themselves and in parallel, it contributed substantially to the discussion on the notion of the biosphere reserve in the region, in fact introducing the theme into strategic planning documents as well as into more practical discussions around tables. First of all, the 
issue itself - sustainable tourism - has been a relatively consensual theme. Secondly, the project yielded concrete and visible outputs, aimed at promoting of sound forms of tourism development. Though the national park was an important project partner, in fact it itself initiated formulation of the project and applied for it, officially the project was coordinated by an independent body (the academician institute) and thus perceived as not being directly linked to the national park and its rather restrictive policy.

The „trade mark“ of the biosphere reserve was used as being in „legislative vacuum“, which was perceived as a weak point at the beginning of the project, namely by the representatives of state nature protection. In the end, however, the legislative vagueness proved to be an advantage as it „liberated“ all the stakeholders from their bred-in-the-bone schematic viewpoints. The project seemed to „break the behavioral stereotypes“, of particular personalities involved. Being mentally „free“ from a legal framework, they behaved rather cooperatively, concentrating on achieving concrete output instead of pushing forward official doctrines of particular institutions they were expected to represent (Kušová et al. 2009).

Formal independence of the projects network from the Šumava National Park and Protected Landscape Area Administration led to the situation when all the partners, including representatives on nature protection themselves, ceased to prejudice and started actively cooperate. The projects network formed thus concrete out-of-official-policystanding platform of cooperation among concrete people, not biased by official doctrines. In this perspective the concept of biosphere reserve itself proved to have a big potential of becoming a good trade mark. Referring to the concept allowed representatives state nature protection „not to lose their face“ when discussing „,developmental issues“" with other stakeholders. The process of achieving desired project outputs proved to be as much important as the outputs themselves, in some perspective even more important, as it enabled linking stakeholders and forming flexible alliances, both formal and informal. Gradual forming and reconstructing of the goal oriented network-like arrangements could be as well interpreted in terms of permanent negotiation process on identity of locality in Bauman's sense (Kušová et al. 2009). The fact, that some of these alliances still continue in their existence is very essential from the perspective of subject discussed in this paper. It suggests these alliances could be hypothesized in terms of emerging institution of commons in the territory of the Šumava Mts., which utilizes the concept of the UNESCO biosphere reserve.

\section{ACKNOVLEDGEMENTS}

The paper was written thanks to the financial support of the Central Europe project „Valorisation and Sustainable Development of Cultural Landscapes using Innovative Participation and Visualisation Techniques VITAL LANDSCAPES" (2CE164P3); and the Czech Science Foundation project „Protected Areas - Social Deal on Nature Protection” (P404/11/0354).

\section{REFERENCES}

Agrawal, A. (1999). Greener pastures: Politics, markets and community among a migrant pastoral people. Durham NC, Duke University Press. 
Agrawal, A. (2001). Common Property Institutions and Sustainable Governance of Resources. World Development, 29: 1649-1672.

Agrawal, A. (2001a). State formation in community spaces? The forest councils of Kumaon. Journal of Asian Studies 60 (1): 1-32.

Amin, A., Thrift, N. (1994). Living in the global. In: Amin, A.. Thrift, N. (Eds.): Globalisation, institutions and regional development in Europe. pp. 1-22. Oxford University Press, Oxford,

Andereck, K. (1997). Territorial Functioning in a Tourism Setting. Annals of Tourism Research, 24: 706-720.

Antrop, M. (2001). The language of landscape ecologists and planners. A comparative content analysis of concepts used in landscape ecology. Landscape and Urban Planning, 55: 163-173.

Antrop, A. (2007). Reflecting upon 25 years of landscape ecology; Editorial. Landscape Ecology, 22: 1441-1443.

Baland, J.M., Platteau, J.P. (1999). The ambiguous impact of inequality on local resources management. World Development 27 (4): 773-788.

Bartoš, M., Kušová, D. \& Těšitel, J. (1998). Integrated endogenous regional development concept and the role of Šumava National Park administration. Silva Gabreta, 2: 385-394.

Bauman, Z. (1999). Globalizace - di̊sledky pro člověka. Mladá fronta, Praha.

Been, V. (1993). What's fairness got do with it? Environmental justice and the sitting locality undesirable land use. Cornell Law Review, 78: 1001-1085.

Berkes, F. (1989). Common property resources: Ecology and community-based sustainable development. Belhaven Press, London.

Blažek, J., Uhlíř D. (2002). Teorie regionálního rozvoje. Karolinum, Praha.

Bramwell, B., Lane, B. (2000). Tourism collaboration and partnerships. Channel View Press, Clevedon.

Briassoulis, H. (2002). Sustainable tourism and the question of the commons. Annals of Tourism Research, 29 (4): 1065-1085.

Brock, W.A., Xepapadeas, A. (2003). Valuing Biodiversity from an Economic Perspective: A Unified Economic, Ecological, and Genetic Approach. The American Economic Review, 93 (5): 1597-1614.

Brunckhorst, D. (2001). Building capital through bioregional planning and biosphere reserve. Ethics in Science and Environmental Politics, 2001:19-32.

Bryant, B. (1995). Environmental Justice: Issues, policies and solutions. Island Press, Washingron, DC.

Bullard, R.D. (1994). Unequal protection: Environmental justice and communitis of color. Sierra Club Books, San Francisko.

Cílek, V. (2010). Krajiny vnitřni a vnější. Druhé vydání, Dokořán, Praha.

Costanza, R., d'Arge, R., de Groot, R., Farber, S.C., Grasso, M., Hannon, B., Limburg, K., Naeem, S., O'Neill, R.V., Paruelo, J., Raskin, R.G., Sutton, P. \& van den Belt, M. (1997). The value of the world's ecosystem services and natural capital. Nature, 387 (6630): 253260.

Crompton, J.L. (1990). Attitude determinants in tourism destination choice. Annals of Tourism Research, 17: 432-448. 
Daily, G.E. (1997). Nature's Services - Societal Dependence on Natural Ecosystems. Island Press, Washington.

Dredge, D. (2006). Policy networks and the local organisation of tourism. Tourism Management, 27: 269-280.

Faber, M. (2008). How to be an Ecological Economist. Discussion Paper Series No. 454, University of Heidelberg.

Ghimire, K., Pimbert, M. (1997). Social change and conservation: an overview of issues and concepts. In: Ghimire, K., Pimbert, M. (Eds.): Social change and conservation: Environmental politics and impacts of national parks and protected areas. Earthscan Publications, London.

Goodal, B., Stabler, M. (2000). Environmental standards and performance measurement in tourism destination development. In: Richards, D., Hall, D. (Eds.): Tourism and sustainable community development. pp. 63-82. Routledge, London,

Gunjan, S. (2005). Relationships, networks and the learning regions: case evidence from the Peak District National Park. Tourism Management, 26: 277-289.

Gunjan, S., Clark, G., Oliver, T. \& Ilbery, B. (2007). Conceptualizing Integrated Rural Tourism. Tourism Geographies, 9 (4):347-370.

Hajer, M. (2003). Policy without polity? Policy analysis and the institutional void. Policy Sciences, 36: 175-195.

Hajer, M. (2003a). A frame in the fields: policymaking and the reinvention of politics. In: Hajer, M., Wagenaar, W. (Eds.): Deliberative Policy Analysis. pp. 88-110. Cambridge University Press, Cambridge,

Hall, D. (2000). Identity, community and sustainability: Prospects for rural tourism in Albania. In: Richards, D., Hall, D. (Eds.): Tourism and sustainable community development. pp. 48-59. Routledge, London

Hayes, T. (2006). Parks, People and Forest Protection: An Institutional Assessment of the Effectiveness of Protected Areas. World Development, 34 (12): 2064-2075.

Healy, R. (1994). The „Common Pool“ Problem in Tourism Landscapes. Annals of Tourism Research, 21: 596-611.

Hillery, M., Nancarrow, B., Griffin, G. \& Syme, G. (2001). Tourist perception of environmental impact. Annals of Tourism Research, 28 (4): 853-867.

Holling, C.S. (2001). Understanding the complexity of economic, social and ecological systems. Ecosystems 4: 390-405.

Imhoff, M.L. (2004). Global patterns in human consumption of net primary production. Nature, 429 (6994): 870-73.

Imperial, M.T. (1999). Institutional Analysis and Ecosystem-Based Management: The Institutional Analysis and Development Framework. Environmental Management, 24 (4): 449-465.

I.U.C.N. (1980). World Conservation Strategy: Living Resources Conservation for Sustainable Development, I.U.C.N., Gland.

Jafari, J. (1982). The Tourism Market Basket of Goods and Services. In: Singh, T., Kaur, J. \& Singh, P. (Eds.): Studies in Tourism Wildlife Parks Conservation, pp. 1-12. New Delhi,

Jamal, T.B., Getz, D. (1995). Collaboration theory and community tourism planning. Annals of Tourism Research, 22: 186-204. 
Kluvánková-Oravská, T., Chobotová, V. (2010). Inštitúcie a ekosystémové služby v demokratickej a trhovej spoločnosti. Životné prostredie 44 (2): 84-87.

Kooten, C.G., Wang, S. (1998). Estimating Economic Costs of Nature Protection: British Columbia's Forest Regulations. Canadian Public Policy - Analyse De Politiques, 24 (2): 63-71.

Kušová, D., Bartoš, M. \& Těšitel, J. (2002). Role of traditions in tourism development in the Czech part of the Bohemian Forest. Silva Gabreta, 8: 265-274.

Kušová, D., Těšitel, J., Matějka, K. \& Bartoš, M. (2008). Biosphere reserves - an attempt to form sustainable landscape (A case study of three biosphere reserves in the Czech Republic). Landscape and Urban Planning, 84 (1): 187-197.

Kušová, D., Těšitel, J. \& Bartoš, M. (2008a). Biosphere reserves - learning sites of sustainable development? Silva Gabreta, 14 (3): 221-234.

Kušová, D., Těšitel, J. \& Bartoš, M. (2008). Biosphere reserves as learning sites for sustainable development (a case study of the Czech Republic). In: Elling, L.R. (Ed.): Social Development. Nova Science Publishers, New York, pp. 87-124,

Long, P. (1994). Perspectives on partnerships as an approach to local tourism development. In: Seaton, A.V. (Eds.): Tourism: the state of the art. Wiley, Chichester.

Lowe, A. (1988). Small Hotel Survival: An inductive approach. The International Journal of Hospitality Management, 7 (3): 197-223.

MacLeod, G. (2001). New Regionalism reconsidered: Globalisation, regulation and the recasting of political economic space. International Journal of Urban and Regional Research, 25: 804-829.

Maskell, P., Malmberg, A. (1999). Localised Learning and Industrial Competitiveness. Cambridge Journal of Economics, 23 (2): 167-186.

Massey, D. (1994). Space, Place and Gender. Policy Press, Cambridge.

McKean, M. (1992). Management of traditional common lands (Iriachi) in Japan. In: Bromely, D. (Ed.): Making the common work: Theory, practice and policy. pp. 63-93. Institute for Contemporary Studies, San Francisco,

McNeely, J. (1995). Expanding partnerships in conservation. Island Press, Washington, DC.

McCay, B.J., Acheson J. (1987). The question of the commons: The culture and ecology of communal resources. University of Arizona Press, Tucson.

Millennium Ecosystem Assessment (2005). Ecosystems and Human Well-being: Synthesis. Island Press, Washington, DC.

Moldan, B., Hák, T. (2010). Klíčové prvky dobrého rozhodování pří managementu ekosystémových služeb. Životné prostredie, 44 (2): 70-73.

Murdoch, J. (2000). Networks - a new paradigm of rural development. Journal of Rural Studies, 16: 407-419.

Naveh, Z. (2001). Ten major premises for a holistic conception of multifunctional landscape. Landscape and Urban Planning, 57 (3-4): 269-284.

Naveh, Z. (2007). Landscape ecology and sustainability. Landscape Ecology, 22 (11): 1437-1440. 
Nolte, B. (2005). Tourism in Biosphärenreservaten Ostmitteleuropas. Hoffnungen, Hindernisse und Handlungsspielräume bei der Umsetzung von Nachhaltigkeit. Mensch and Buch Verlag, Berlin.

Ostrom, E. (1990). Governing the commons: The evolution of institutions for collective action. Cambridge University Press, Cambridge.

Ostrom, E. (1992). Crafting institutions for self-governing irrigation systems. Institute for Contemporary Studies, San Francisco.

Ostrom, E. (1999). Self governance and forest resources. Occasional Paper No. 20, Center for International Forestry Research, Bagor, Indonesia. Retrieved 2010-05-06, from http://www.cgir.org/cifor

Paiders, J. (2007). How nature protection restrictions affect economic development? An example of municipalities from the North Vidzeme Biosphere Reserve, Latvia. Working paper, University of Latvia.

Palang, H., Helmfrid, S., Antrop, M. \& Alumäe, H. (2005). Rural Landscapes: past processes and future strategies. Landscape and Urban Planning, 70: 3-8.

Parto, S. (2005). „, Good“ Governance and Policy Analysis: What of Institutions?. MERITInfonomics Research Memorandum series 2005-001, Maastricht Economic Research Institute on Innovation and Technology.

Palmer, A. (1998). Evaluating the governance style of marketing groups. Annals of Tourism Research, 25 (1): 185-201.

Petrova, S., Bouzarovski-Buzar, S. \& Čihař, M. (2009). From inflexible legislation to flexible local governance: management practices in the Pelister National Park, Republic Macedonia. GeoJournal 74: 589-598.

Pimbert, M.P., Pretty, J.N. (1995). Parks, people and professionals: Putting „Participation“ into protected areas management. Discussion Paper No. 57, Geneva United Nations Research Institute for Sustainable Development.

Pretty, J.N. (1995). The many interpretation of participation. Focus 16: 4-5.

Roth, S. (2007). Summary of Outcomes of the Workshop on NATURA 2000 and Tourism. Ecological Tourism Europe, Bonn.

Selsky, J., Memon, P. (2000). Emergent Commons: Local Responses in Complex CPR System. Paper presented at the $8^{\text {th }}$ IASCP Conference, Bloomington, Indiana

Shaw, G., Williams, A.M. (1994). Critical issues in tourism: A geographical perspective. Blackwell, Oxford.

Stevens, S. (1997). New alliances for conservation. In: Stevens, S. (Ed.): Conservation through cultural survival. Island Press, Washington, DC.

Stoll-Kleemann, S., Bender, S., Berghöfer, A., Bertzky, M., Fritz-Vietta, N., Schliep, R. \& Thierfelder, B. (2006). Linking Governance and Management Perspectives with Conservation Success in Protected Areas and Biosphere Reserves. Discussion paper 01 of the GoBi Research Group, Humboldt-Universität, Berlin.

Storper, M. (1997). The regional world: Territorial development in a global economy. Guilford Press, London.

Tait, J., Lyall, C. (2004). A New Mode of Governance for Science, Technology, Risk and the Environment? Innogen Working Paper 17 
Těšitel, J., Kušová, D. \& Bartoš, M. (1999). Non marginal parameters of marginal areas. Ekológia (Bratislava), 18 (2): 39-46.

Těšitel, J., Kušová, D. \& Bartoš, M. (2003). Tourist's reasons for visiting mountain areas: a case study of the Šumava Mountains. Landscape Research, 28 (3): 317-322.

Těšitel, J., Kušová, D. \& Bartoš, M. (2003a). Role of tourism in development of rural marginal areas (region Šumava Mts., Czech Republic). In: Banski, J., Owsinski J. (Eds.): Alternatives for European Rural Areas. pp. 81-91. European Rural Development Network, Institute of Agricultural and Food Economics, Institute of Geography and Spatial Organization, Polish Academy of Sciences, Warsaw

Těšitel, J., Kušová, D. \& Bartoš, M. (2006). Rural areas development - local needs and external forces. In: Florianczyk, Z., Czapiewski, K. (Eds.): Rural Development Capacity in Carpathian Europe. pp. 87 - 97. European Rural Development Network, Institute of Agricultural and Food Economics, Institute of Geography and Spatial Organization, Polish Academy of Science, Warsaw

Těšitel, J., Kušová, D. \& Bartoš, M. (2007). Šetrný turismus v biosférických rezervacich nástroj formování sití spolupráce: prípadová studie Biosférické rezervace Šumava. Úřad vlády Korutan, Klagenfurt.

Troll, C. (1939). Luftbildplan und ökologische Bodenforschung. Zeitschrift der Gesellschaft für Erdkunde, Berlin.

UNESCO (1996). Biosphere Reserves: The Seville Strategy and the Statutory Framework of the World Network. UNESCO, Paris.

UNESCO (2001). Seville+5 International Meeting of Experts in Pamplona (Spain, 2000), Proceedings - MAB Report Series No. 69, UNESCO, Paris.

UNESCO (2002). Biosphere reserves: Special places for people and nature. UNESCO, Paris.

UNESCO (2008). The Madrid Declaration. UNESCO, Paris.

Urban, F. (2006). Institutional and management frameworks in the Biosphere Reserve Šumava. Ecological Tourism Europe, Bonn.

Wells, M.P., Brandon, K. (1992). People and parks: Linking protected area management with local communities. World Bank, Washington, DC.

Welsh, M.P., McShane, T.O. (2004). Integrating protected areas management with local needs and aspirations. AMBIO: Journal of the Human Environment, 33: 513-519.

Western, D. (1997). In the dust of Kilimanjaro. Island Press, Washington, DC.

Western, D., Wright, M. (1994). Natural connections: Perspectives in community-based conservation. Island Press, Washington, DC.

Wood, A., Stedman-Edwards, P. \& Mang, J. (2000). The Root Causes of Biodiversity Loss. Earthscan, London. 